\title{
How Ground Penetrating Radar helps to understand the Nhecolândia lakes landscape in the Brazilian Pantanal wetland
}

\author{
Fabio Taioli1* (D), Mauricio Guerreiro Martinho dos Santos ${ }^{2}$ (D), Mario Luis Assine ${ }^{3}$ (D), Deborah Mendes ${ }^{4}$ (D)
}

\begin{abstract}
The Pantanal wetland is an active sedimentary basin representing a relevant depositional setting for alluvial sedimentation studies. However, sedimentation homogeneity and the lack of outcrops makes sedimentary analysis more difficult. The Lower Nhecolândia is located at the Southern edge of the Taquari river megafan, whose genetic origin has been disputed as fluvial or eolian deposition. GPR analysis was used to characterize the subsurface stratigraphy and understand the region's geomorphic evolution. The $100 \mathrm{MHz}$ GPR provided continuous good quality sections up to a depth of $8 \mathrm{~m}$. Two continuous reflections are disconformities that bound three depositional sequences characterized by distinct radar facies. The lower facies presents an upper erosional truncation followed by reflections presenting $\sim 1.5 \mathrm{~m}$ deep channelized forms and concave-up low amplitude reflections. The intermediate facies $(\sim 4 \mathrm{~m}$ thick) presents a base with erosional truncation followed by concave-upward forms, $\sim 10 \mathrm{~m}$ wide, 1-3 m deep, separated by 1-2 m, and offlapping geometry. The upper facies has a flat base and thickness of $2-4 \mathrm{~m}$, with parallel reflections; it shows a strong correlation between the radar facies and the forms preserved in the landscape, suggesting that channelized fluvial streams did not form them. The results obtained indicate that GPR use in the Pantanal is an important method to elucidate its geologic evolution.
\end{abstract}

KEYWORDS: Pantanal Basin; ground penetrating radar; Taquari megafan; radar facies; shallow stratigraphy.

\section{INTRODUCTION}

The Pantanal region, located in West Central Brazil, is one of the most important wetlands in the world (Por 1995, Junk et al. 2006), with large pristine alluvial plains (Assine 2015). It is an important depositional site where modern alluvial sedimentation can be studied (Assine and Soares 2004, Assine 2005, Assine $e t$ al. $2015 b)$. The alluvial plain offers the opportunity to link the vertical sections of the subsurface with the depositional forms that are preserved in the landscape, allowing 3D analysis of the depositional architecture. However, facies analysis is extremely difficult due to the absence of natural outcrops and the homogeneity of sediments, which consists mainly of medium to fine-grained sand.

Considering the scarcity of outcrops, the ground penetrating radar (GPR) can be an important tool to help to understand the current and past depositional systems in the alluvial plain. The use of GPR enables the evaluation of geomorphic features

\footnotetext{
${ }^{1}$ Instituto de Energia e Ambiente, Universidade de São Paulo - São Paulo (SP), Brazil. E-mail: ftaioli@usp.br

${ }^{2}$ Universidade Federal do ABC - Santo André (SP), Brazil. E-mails: mauriciogmsantos@gmail.com, santos.mauricio@ufabc.edu.br

${ }^{3}$ Departamento de Geologia Aplicada, Universidade Estadual Paulista "Júlio de Mesquita Filho” - Rio Claro (SP), Brazil. E-mail: mario.assine@unesp.br

${ }^{4}$ Geologia e Recursos Minerais, Serviço Geológico do Brasil Ringgold Standard Institution - São Paulo (SP), Brazil. E-mail: dhmendes@ alumni.usp.br

${ }^{*}$ Corresponding author.
}

(C) 2021 The authors. This is an open access article distributed under the terms of the Creative Commons license. and helps to identify possible anomalies, discontinuities, buried anthropic artifacts and geological structures such as facies variations, thus optimizing the costs of surveys. GPR analysis in depositional river systems benefits from the variability of river systems and has been used in several large-scale studies (Bridge et al. 1995, Van Overmeeren 1998, Bristow and Jol 2003, Neal 2004, Smith et al. 2006, Smith et al. 2009, Tatum and Francke 2012, Lopes et al. 2013, Tamura et al. 2016). Subsurface investigations using GPR in modern deposition sites in the Pantanal were solely conducted in the modern Taquari river channel (Souza et al. 2002, Porsani et al. 2005).

To evaluate the applicability of GPR in characterizing the subsurface stratigraphy and in understanding the geomorphic evolution of the Pantanal wetland (Fig. 1), we have investigated the enigmatic landscape of the Lower Nhecolândia, in the Southern fringe of the Taquari fluvial megafan (Assine et al.2015b, Assine et al. 2015c). The genetic origin of the Lower Nhecolândia landscape is disputed (Assine et al. 2015c), being interpreted as fluvial (e.g., Ab'Saber 1988, Colinvaux et al. 2000, Barbiéro et al.2002, Furquim et al.2010) or eolian relict landforms (e.g., Klammer 1982, Tricart 1982, Assine and Soares 2004, McGlue et al.2017). Therefore, the imaging of the Nhecolândia subsurface characteristics can clarify these discussions, with a perspective of conclusive results concerning the pointed hypothesis.

\section{GEOLOGICAL SETTING}

The Pantanal Basin is a subsiding sedimentary basin located in West Central Brazil. It is related to the hydrographic basin 
of the upper Paraguay River (Ussami et al. 1999, Assine and Soares 2004). It is characterized by an extensive alluvial plain that is flooded annually and displays a relatively flat topography. Altitude values range from 80 to $190 \mathrm{~m}$, and topographic gradient varies from 0.3 to $0.5 \mathrm{~m} / \mathrm{km}(\mathrm{E}-\mathrm{W})$ and 0.03 to $0.15 \mathrm{~m} / \mathrm{km}(\mathrm{N}-\mathrm{S})$ (Assine 2003). The Pantanal alluvial plain is characterized by a complex arrangement of different alluvial system tracts: distinct fluvial systems originated in the surrounding basement areas flow into the basin, where they develop different types of fluvial-fan (e.g., Negro River), megafan (e.g., Taquari River), interfan systems (e.g., Piquiri River), and a trunk-river system (i.e., the Paraguay River). The hydrologic regime and sedimentary dynamics of the Pantanal fluvial systems are determined by the geology and geomorphology of these systems' basement source-areas, which consists of both Precambrian crystalline rocks and Palaeozoic to Mesozoic rocks related to the Paraná Basin (Fig. 1; Assine et al. 2015a).

The Taquari Megafan (Assine 2005) is the largest megafan in the Pantanal plains, with approximately $50,000 \mathrm{~km}^{2}$, about $37 \%$ of the Pantanal Basin total area (Assine 2003, Zani et al. 2012). It is composed of 4 geomorphologic components:
- the incised meander belt to the East;

- the modern depositional lobes to the West;

- the abandoned lobes to the North (Paiaguás);

- the abandoned lobes of the Nhecolândia to the South (Assine 2005, Assine et al. 2005).

The meander belt is confined in an incised valley in the upper portion of the megafan, which functions as a bypass for the water and sediment sourced from the Eastern plateau to the modern depositional lobes where the bulk of sedimentation is currently taking place. The Paiaguás and Nhecolândia paleolobes are not currently being fed by the Taquari River, and their runoffs have a pluvial origin (Assine et al. 2015a). The Paiaguás paleolobes are characterized by an intricate network of distributary paleochannels (Assine 2005) with distinct dimensions, superposing and cross-cutting planform patterns, similarly to those preserved in the São Lourenço Megafan (Assine et al. 2015b), a coalescing depositional system located to the North of the Taquari River and separated by the latter by the interfan plain of the Piquiri River (Assine et al. 2015b).

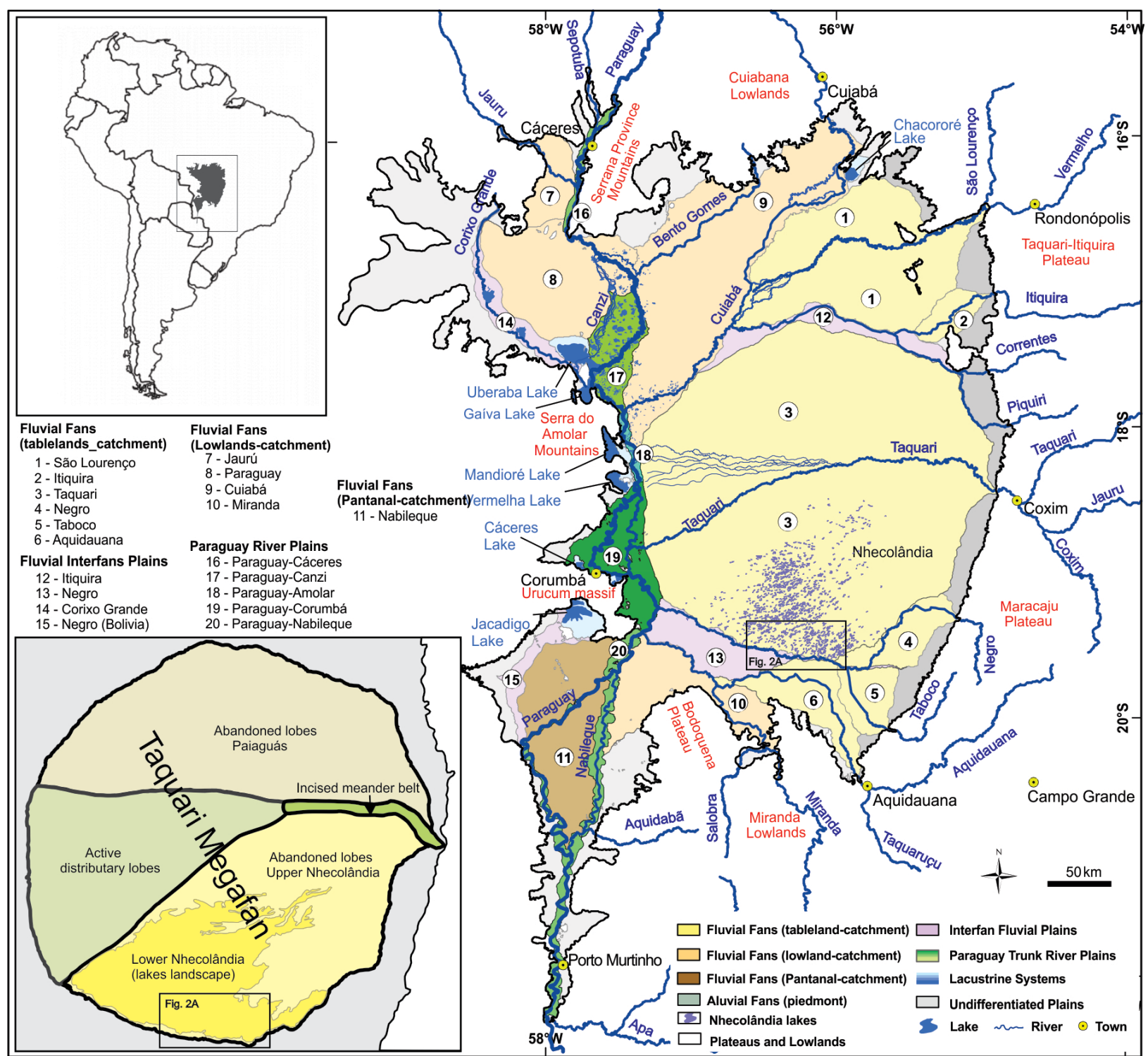

Figure 1. Depositional system tract of the Pantanal Basin (after Assine et al. 2015a) showing Figure 2 area. Lower-left square shows the incised meander belt, as well as the active and abandoned lobes of the Taquari megafan. 
The Nhecolândia lobes are currently experiencing degradation through erosional tributary intermittent channels that drain floodwaters to the interfan system of the Negro River (Assine et al. 2015b). Two distinct geomorphologic zones characterize the Nhecolândia region: the upper Nhecolândia, characterized by distributary paleochannels with apexes on proximal areas of the megafan; and the myriads of ponds composing the Lower Nhecolândia (Assine and Soares 2004, Evans and Costa 2013) (Fig. 2).

The Lower Nhecolândia is a unique landscape in the wetland, characterized by aligned lakes bordered by sand ridges (locally named "cordilheiras"), which are only a few meters higher than the lake's bottom. Freshwater lakes ("baías") are interconnected by small intermittent stream ("corixos" or "vazantes") and reached by surface runoff during floods. Alkaline lakes ("salinas") make up for less than $10 \%$ of the Lower Nhecolândia and are rarely invaded by floodwaters; their waters are characterized by varied levels of salinity (Barbiéro et al. 2008, Furian et al. 2013, Bergier et al. 2014).

\section{METHODS AND MATERIALS}

Ground penetrating radar (GPR) is a near-surface geophysical technique based on the emission and reception of high frequency $(10-1,000 \mathrm{MHz})$ electromagnetic waves in the subsurface. The electromagnetic wave reflections in the subsurface occur at the interfaces of materials with different dielectric properties. The physical property involved in this phenomenon is the dielectric permittivity, which is expressed by the dielectric constant (K) (Davis and Annan 1989). The higher the permittivity difference between the materials, the greater the reflected energy. The method works particularly well in dry materials with high electrical resistivity. Neal (2004) presents an excellent introduction to the GPR method, data processing, radar facies descriptions and interpretation.

GPR provides continuous sections in real-time (two-way travel time through a distance $\mathrm{x}$ ) profiles performed in the field, and allows high-resolution imaging of the subsurface structures. The two-way travel time can be converted accurately into depth by running a particular sounding (wide-angle reflection
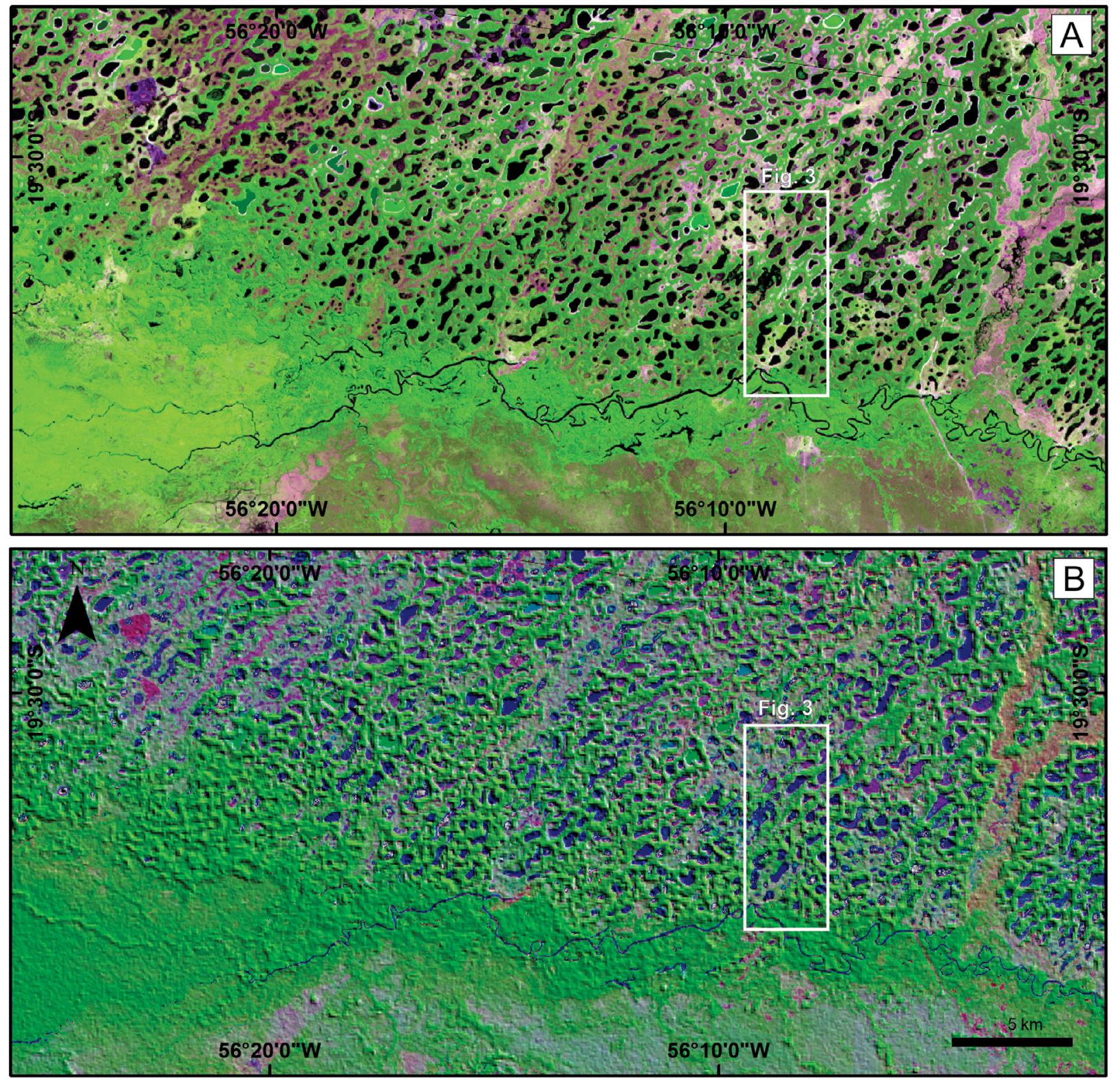

Figure 2. Lakes landscape of the lower Nhecolândia in the Southern fringe of the Taquari fluvial megafan, bordering the Negro River interfan system (Merino and Assine 2020). The white rectangle is the study area that is portrayed in Figure 3. 
and refraction - WARR or Common Mid-Point - CMP). Permittivity values obtained from reliable literature with known study materials based on homogeneous lithology may also be used for the conversion of times to depths.

In this study, GPR equipment was used (from IDS Ingegneria Dei Sistemi SPA). The equipment is composed of two antennas (transmitter and receiver) with a coupled odometer, a control unit (DAD Control Unit) and a portable computer. The control unit (DAD) generates a pulse that is sent to the transmitting antenna. The signal then travels through the investigated substrate. Upon return, it is collected by the receiving antenna before it is scanned and displayed on the microcomputer monitor in the form of wave amplitude versus time plot. Accurate information of the traversal distance is given by a pulley (odometer), which generates a pulse at pre-set intervals, with each pulse corresponding to a data acquisition scan. The distance between scans was set to $4 \mathrm{~cm}$ in the software that manages all other data acquisition parameters, as well as the presentation of radargram (section time versus distance traveled). Antennas with a $100 \mathrm{MHz}$ frequency were used due to their ability to allow relatively greater penetration in the geological environment while maintaining a vertical resolution of about $25 \mathrm{~cm}$ in the sandy lithology. The configuration used in this environment allows one to investigate depths of up to $8 \mathrm{~m}$.

Although GPR data interpretation is based on electromagnetic waves, the sections' processing is similar to that applied to seismic reflection data when using the common offset technique. A software (GRED) was used for the conventional data processing and involved the following steps:

- zero-time correction (zero-drift time): to eliminate the wave travel time in the interface space between the antennas and the topsoil;

- Signal saturation correction by removing low frequencies (dewow): a low-pass filter that eliminates the wave interference propagated through the air;

- application gains for attenuated signals: to apply a gain curve which essentially compensates the natural spherical decay suffered by the signal;

- application of a frequency filter (band pass vertical): used in the attenuation of high-frequency noise inherent to the device;

- application of spatial filters (2D) for smoothing the reflections.

The generated section was then exported to another software (Reflex), in which topographic correction was applied and the final section was created. The propagation speed was measured by setting several diffraction hyperboles present in the section, reaching an average speed of $0.100 \mathrm{~m} / \mathrm{s}$ (a number used to convert two-way travel time to depth). This value is consistent with the literature (e.g., Neal 2004, Jol and Bristow 2003).

Altitudes in the study area vary slightly (between 114 and $118 \mathrm{~m}$ ). As such, there is a need for topographic corrections particularly in the study of depositional systems, where subtle variations in inclination may result in misinterpretation. This process helps to adjust the reflections to become more reliable in the section. A Trimble DGPS was used for the correct spatial positioning in both coordinates and altitude, allowing better precision than $5 \mathrm{~cm}$ in height. Points were collected every 5 meters and were used in the GPR data processing.

According to Neal (2004), although much of the terminology associated with seismic stratigraphy can be applied directly to the radar stratigraphy, it is recommended that the approach be changed. This is because interpretations tend to mix descriptive and interpretative terms, especially regarding the definition of facies, which may not be correct if the context in which the terms are used is not specified. Furthermore, where the descriptive terms have been used, they are often poorly defined. Thus, for each reflection, or each radar facies, or each reflection's package, the ideal situation is to consider the shape, dip, continuity, amplitude and relationship between the reflections.

Radar facies are interpreted to record depositional sedimentary structures. As such, a sequence stratigraphic analysis was applied to interpret different depositional sequences similarly to those used in seismic interpretation. Depositional sequences record sedimentary cycles (Vail et al. 1977) and are defined as genetically related sediment bodies that are bounded by unconformities or correlative conformities (Posamentier and Vail 1988, Van Wagoner et al. 1988). Thus, the methodology applied to siliciclastic sequence stratigraphy (e.g. Posamentier and Allen 1999) was used and adapted to the continental environment.

\section{RESULTS}

Two sites were investigated in the Barranco Alto farm, in the Southernmost part of the Nhecolândia (Fig. 3). In both areas, GPR sections were surveyed approximately in the directions NE-SW and NW-SE, respectively parallel and perpendicular to the surface runoff which flows to the South of the Negro River. The GPR technique applied to the sedimentation study in the Taquari megafan provided continuous sections. Due to the lithologic composition of the sediments, it was possible to reach depths of up to 8 meters with a vertical resolution of about $25 \mathrm{~cm}$ and horizontal resolution of $5 \mathrm{~cm}$ using $100 \mathrm{MHz}$ antennas. This allowed the characterization of the reflections' architecture (in radargrams) and the identification of sedimentation patterns that a direct method of geological research would hardly demonstrate. The data were generally of good quality. Despite the good penetration considering the study's goal, it might be jeopardized by the electrical conductivity of the groundwater, which can reach more than $10,000 \mu \mathrm{S} / \mathrm{cm}$ and have $\mathrm{pH}>9$ (Almeida et al. 2011).

Five sections were surveyed near the Barranco Alto farm headquarters (approximate coordinates: 1934'10” S 560' 40” W), and other three approximately $8 \mathrm{~km}$ to its North (approximate coordinates: $19^{\circ} 31^{\prime \prime} 40^{\prime \prime} \mathrm{S}$ and $56^{\circ} 08^{\prime} 40^{\prime \prime} \mathrm{W}$ ). Sections 1,2 and 3 (Fig. 3B) are perpendicular to the surface-runoff direction (NW$\mathrm{SE}$ ), whereas sections 4 and 5 are parallel to the surface-runoff direction (NE-SW). It forms a grid covering a total length of $1,875 \mathrm{~m}$. The radar facies classification was written according to previous research proposed by Neal (2004). The stratigraphic interpretation of the processed sections shows two disconformities, recognized in all sections. Three sedimentary units (Figs. 4 and 5) were also recognized. Local relief is characterized by the presence of sand ridges between the lakes; as such, topographic 
corrections were applied during the GPR data processing of the NW-SE sections (low-pass filter). However, this procedure introduced a slightly high-frequency noise that could not be extracted and was important during the verification of the continuity between both disconformities, as shown in Figure 4 .

The disconformities individualized three different depositional sequences (Table 1), which were named Unit 1, 2 and 3, from the oldest to the most recent one, respectively. It was impossible to identify the base of Unit 1 (lowest) due to limitations in the GPR signal-penetration. The radar facies of the upper limit in Unit 1 are characterized by erosional truncation with concave-up geometries. The resolution decreases with depth (most likely due to humidity increase). Internal reflections of Unit 1 are mainly characterized by a chaotic pattern, with some concave-up and channelized forms. The sedimentological interpretation of Unit 1 is limited by low resolution as a greater depth is achieved, as well as a considerable amount of noise (most likely due to humidity increase). Although geologic reflections are chaotic and have a short lateral extent (discontinuous), the identified concave-up erosional features and channelized forms are filled with relatively flat-lying deposits. This suggests fluvial deposition, with preservation of both horizontal stratification and cross-stratification, along with the fan's overall depositional environment.

The base of Unit 2 (intermediate) is very irregular and characterized by various concave-up geometries. This suggests deposition by rivers characterized by braided channels, contrasting with current characteristics of active channels in the megafan. The unit is approximately $1 \mathrm{~m}$ thick, but can be up to $4 \mathrm{~m}$ deep depending on its location. Radar facies of various types were characterized by subparallel, oblique, concave-upward forms, approximately $10 \mathrm{~m}$ wide and $1-3 \mathrm{~m}$ deep, separated from each other by $1-2 \mathrm{~m}$, and offlapping geometries. The upper boundary is concordant and nearly parallel with the pattern of Unit 3 . The reflections' configurations suggest a stratigraphy composed of channels, ranging between $15-40 \mathrm{~m}$ wide, filled with fluvial bar sets (Figs. 4 and 7).
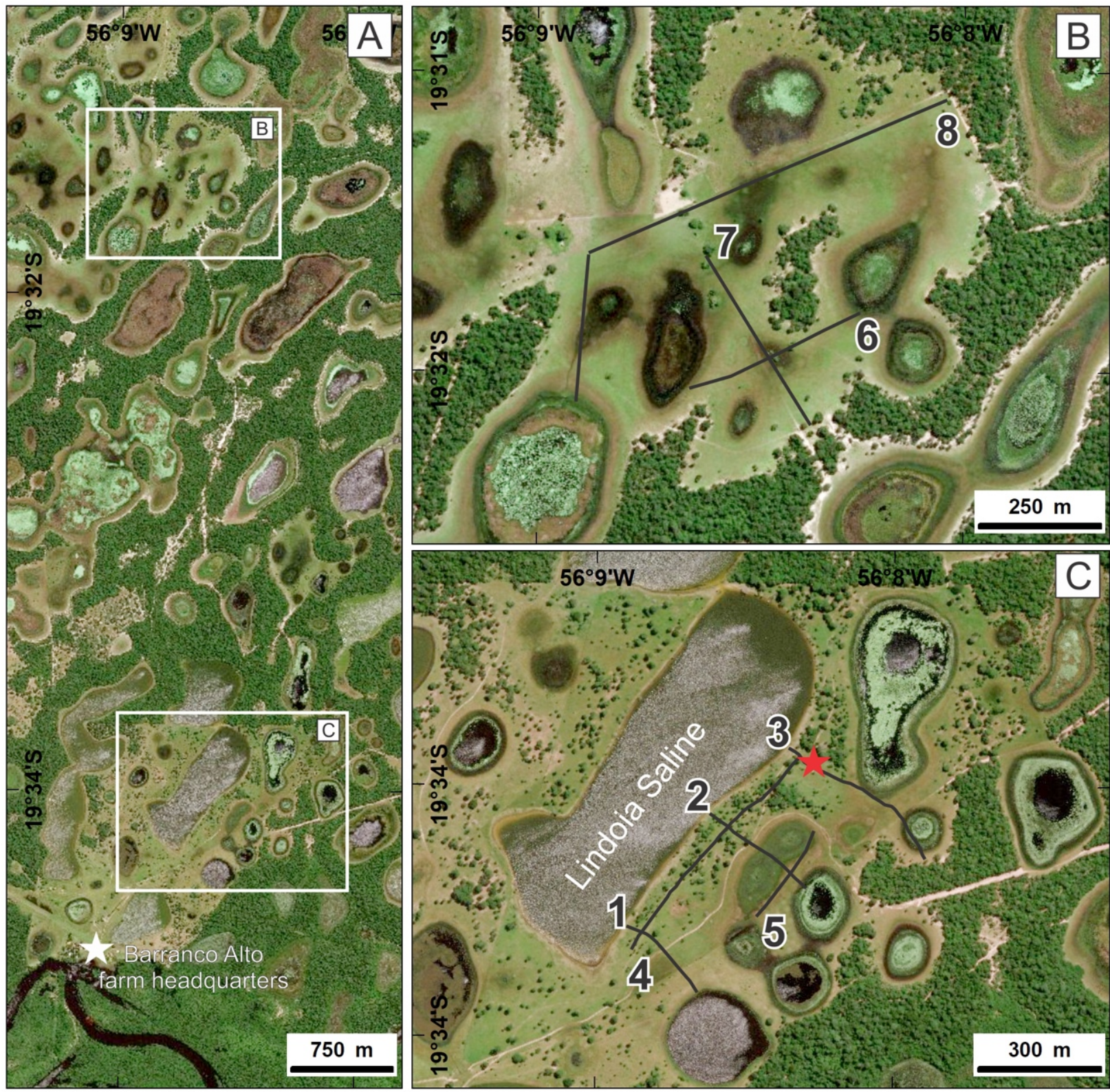

Figure 3. Location of the GPR sections. (A) Overview of the study area in the Nhecolândia region, showing the Negro River in the southern part of the image as well as the location of (B) and (C). (B) Location of sections $6-8$. (C) Location of sections $1-5$, showing the Lindóia Saline. The red star indicates the location of the pit excavation site (sediment profile as shown in Figure 8). 

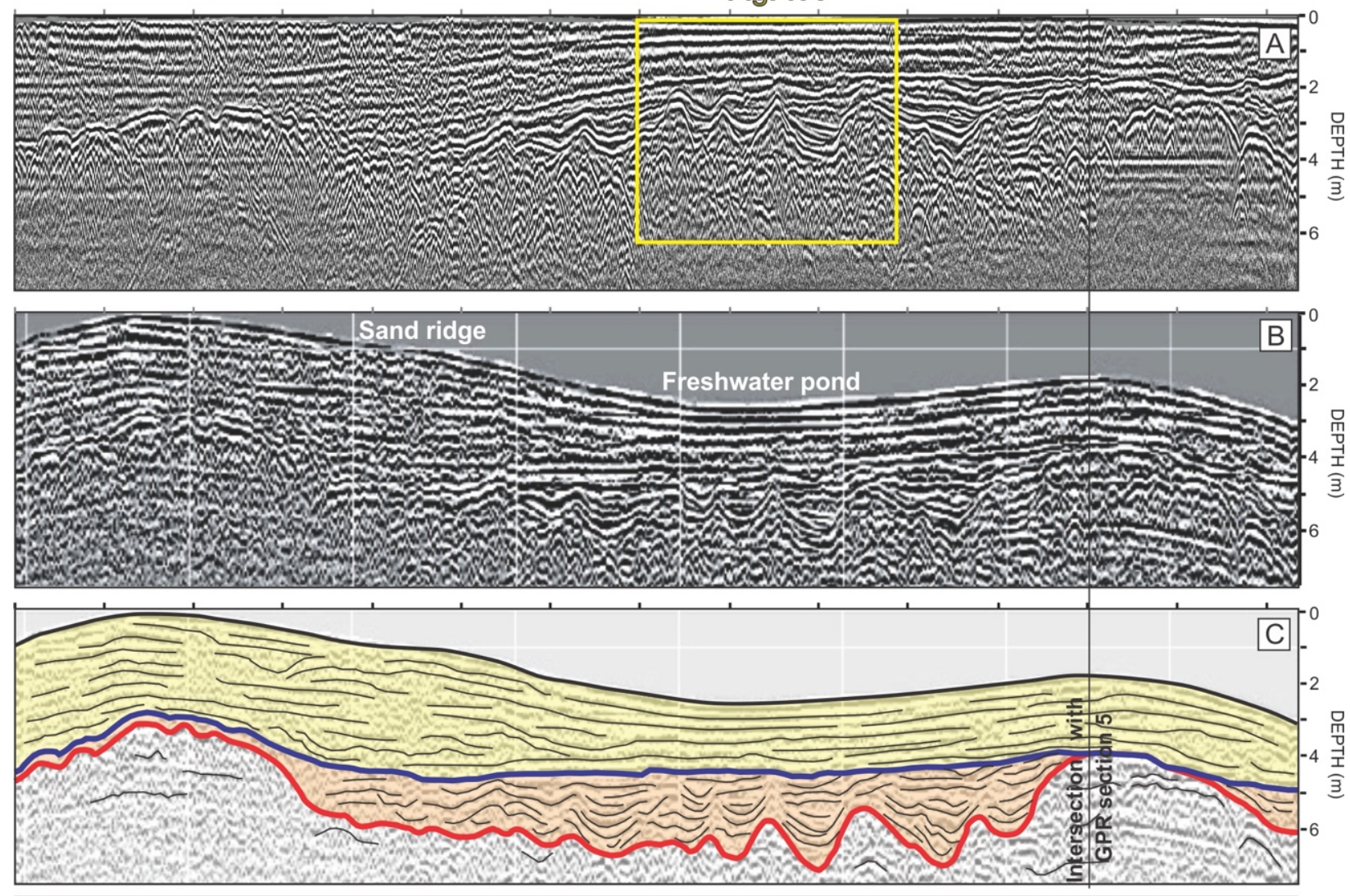

$\begin{array}{llllllll}\square & \text { Unit } 3 & \square & \text { Unit } 2 & \square & \text { Unit } 1 \quad \text { disconformity } 2 & \text { disconformity } 1 \quad \text { reflections }\end{array}$

Figure 4. GPR section 2 near the Lindóia Saline (see Figure 3C for location). The GPR section is presented (A) without and (B) with topographic correction. The section is perpendicular to the surface runoff and runs from one sand ridge to another while crossing a small freshwater pond. The irregular nature of disconformity 1 can be observed through multiple concave-up sections which might indicate deposition by multi-channel fluvial planform. The yellow square indicates the location of the section in Figure 7A.

200

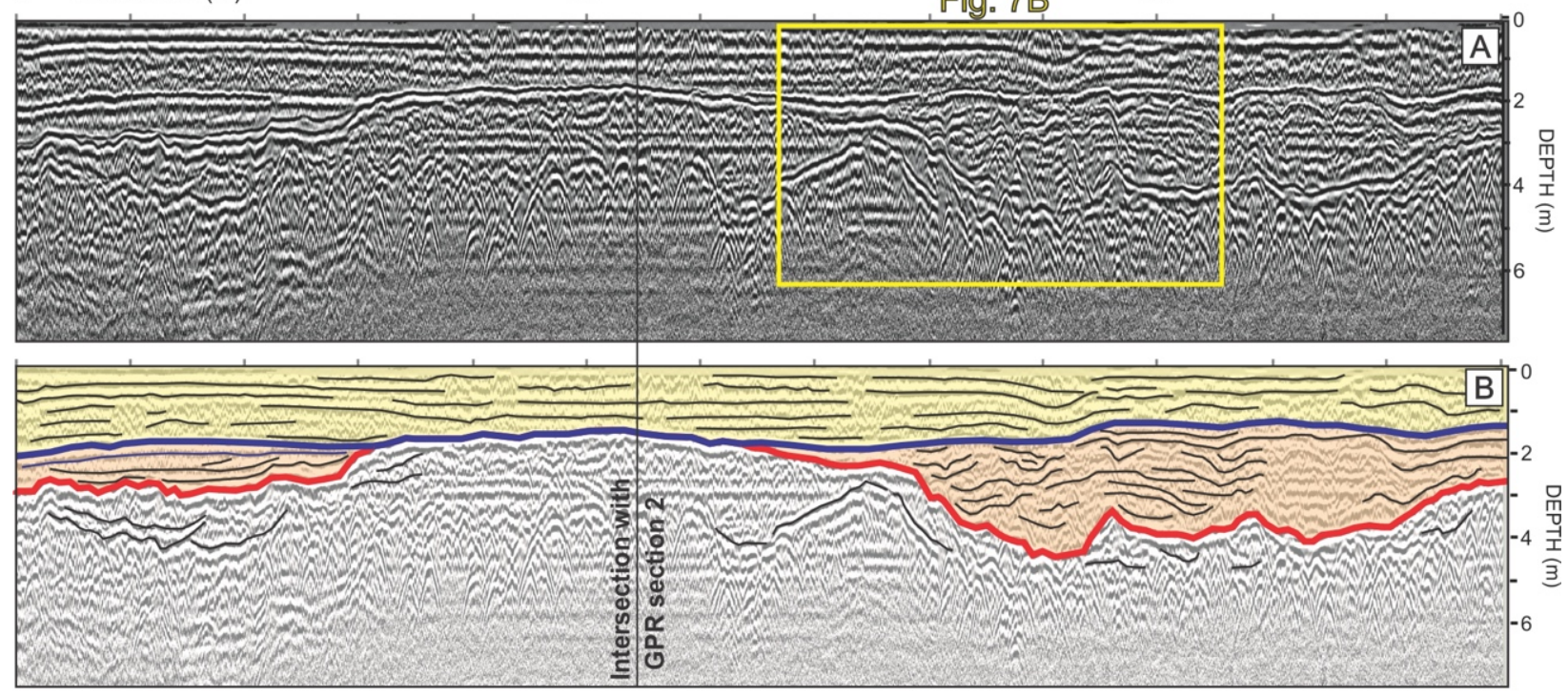

Unit 3

Unit 2

Unit 1

disconformity 2

disconformity 1 reflections

Figure 5. GPR section 5, acquired parallel to the Lindóia Salina and the surface runoff (see Figure 3C for location). The topographic surface is flat and no elevation corrections were applied. Disconformity 1 shows an incision of up to 3 meters and a concave-up profile, while disconformity 2 is characterized by a relatively flat geometry, concordant with the overlying reflections. The yellow square indicates the location of the section in Figure 7B. 
Unit 3 (upper facies) has a flat and slightly irregular base and comprises the most recent deposits of Nhecolândia. The unit is approximately $2-4 \mathrm{~m}$ thick, and the radar facies are characterized by roughly parallel internal reflections that can laterally present divergent and convergent configurations. Radar facies geometry also indicates vertical aggradation in the lower units. Stratigraphically, the reflections exhibit low-angle convex-upward geometry beneath the sand ridges (cordilheiras), but pinch out laterally towards the ponds where they are mostly near horizontal.

In contrast with the morphology of ponds and sand ridges that characterize the site near the farm headquarters, the site situated $8 \mathrm{~km}$ to the North is a flat area where the lake landscape is being obliterated by sheet-flowing waters (Fig. 3C).
Relict-ponds morphology can be seen during the dry season, but they are connected by surface runoff waters during floods. Due to this flatness, no topographic correction was necessary during the GPR data processing, and the three sections (4, 5 and 6) are of good quality. In the surveyed sections, the two disconformities were easily recognized, and units 2 and 3 present the same patterns observed in the Southernmost sections (Fig. 6).

\section{DISCUSSION}

The GPR technique has been successfully used in the emerged areas of the Pantanal Basin to investigate shallow stratigraphy and sedimentation patterns. The data presented

SW

200

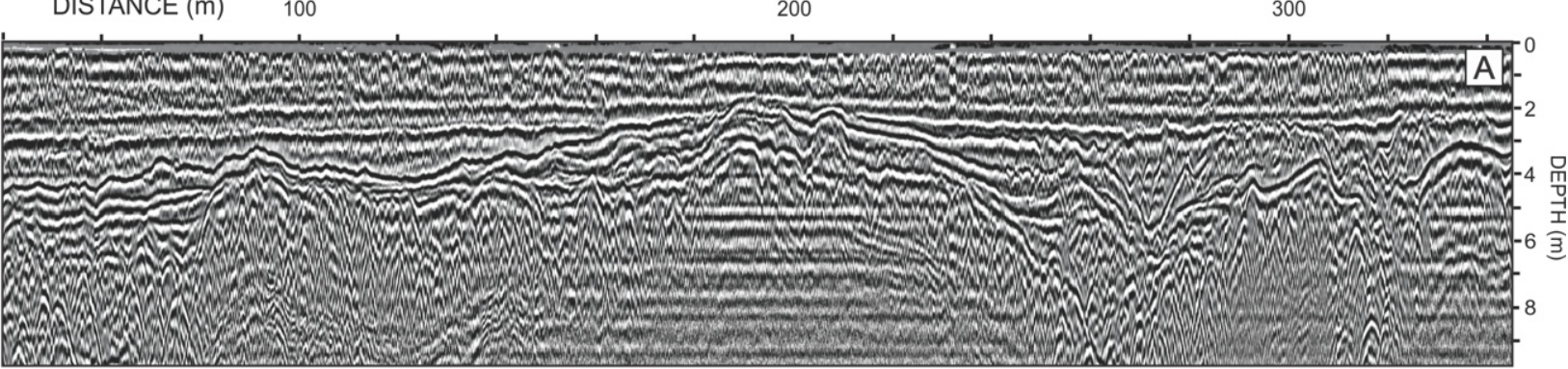

NE

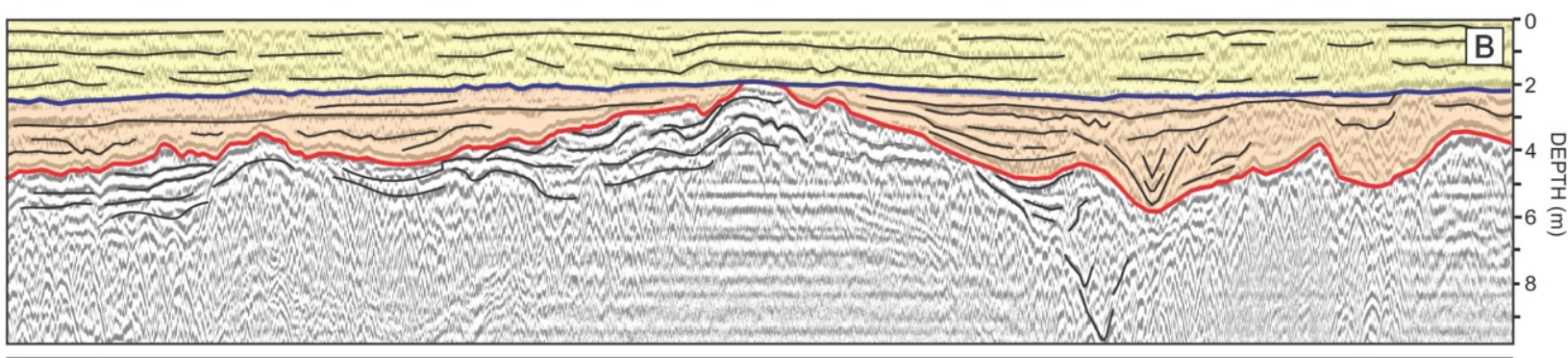

Unit 3

Unit 2

Unit $1-$ disconformity 1 disconformity 2 reflections

Figure 6. GPR section 6 (see Figure 3B for location), acquired perpendicularly to the surface runoff, in a flat surface (no elevation corrections were made). Disconformity 1 shows two distinct concave-up sections with up to $3 \mathrm{~m}$-deep incisions.

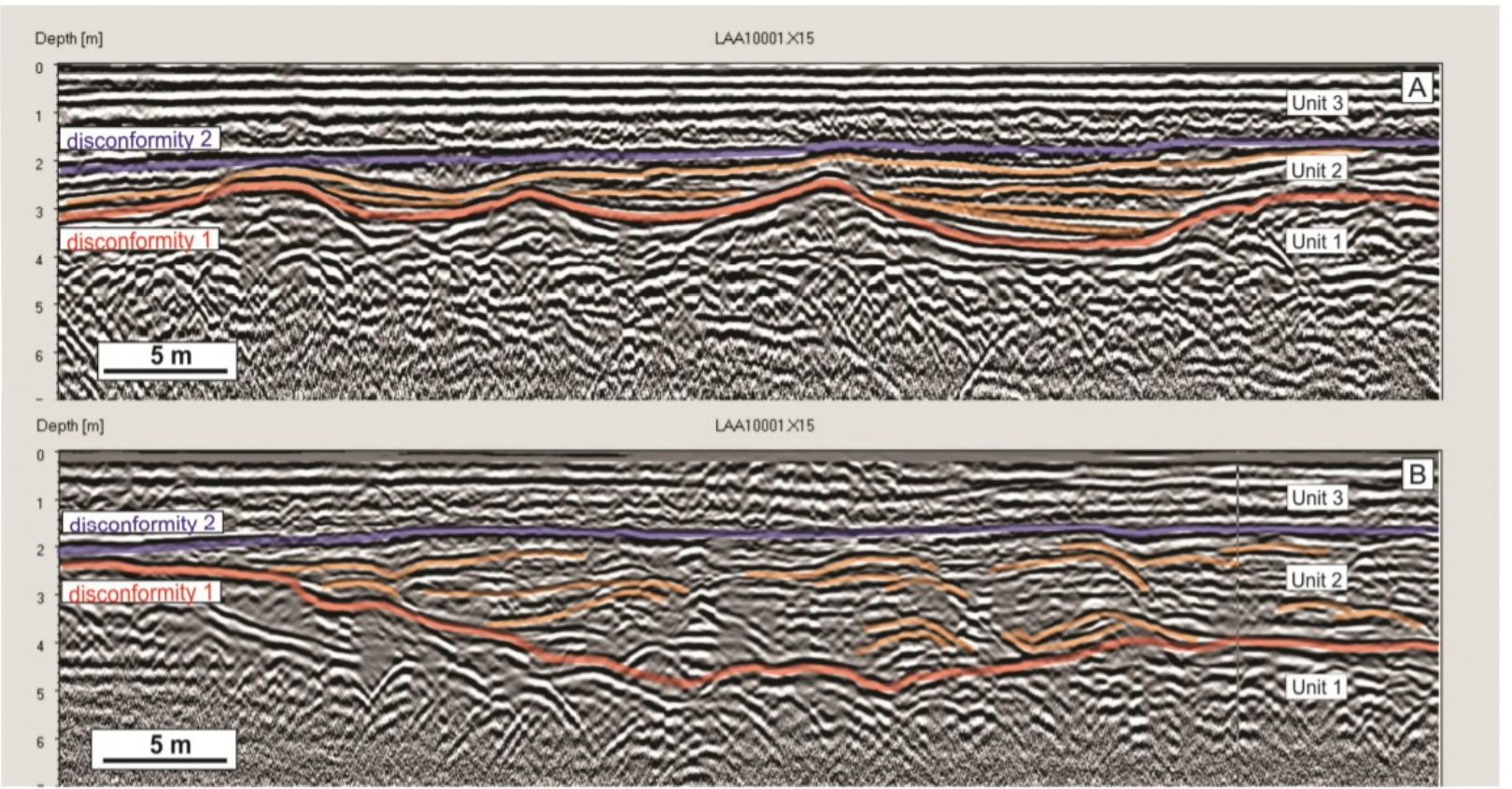

Figure 7. Fluvial channel-fill architectural elements: (A) Bar set perpendicularly to paleoflow in section 2 (location as shown in Figure 4); (B) Bar set parallel to paleoflow in section 5 (see Figure 5 for location). See Figure 3C for location. 
herein provides crucial information on the depositional history of the Taquari megafan, allowing the interpretation of river regimes that prevailed in the region in the past. This pioneering approach of the Taquari region allows for considerable progress in understanding the past dynamics of the alluvial rivers of the Pantanal. It enabled the identification and recognition of a number of depositional environments, ranging from distinct fluvial styles in the lowermost successions and eolian deposition and re-working at the uppermost succession.

Analyses on GPR profiles allowed the identification of two main discontinuities separating three depositional units. Unit 1 is characterized by a somewhat chaotic pattern of reflections that are commonly truncated and locally characterized by concave-up geometries. Some of the reflections are relatively continuous laterally and characterized by irregularities, with concave-up geometry locally. This unit's collective characteristics are indicative of fluvial deposition, even though the quality of the section in this particular stratum decreases with depth.
Reflections of Unit 2 (intermediate) exhibit erosive bases and aggrading geometries, with some reflections truncated by each other and others characterized by horizontal-parallel geometry. The basal reflection of this unit is irregular, presenting troughs and ridges, as opposed to the upper reflection, which is mostly horizontal; locally, the upper reflection drapes the ridges formed by the lower bounding surface. The characteristics observed in Unit 2 indicate fluvial-system deposition preserved in the subsurface of the Nhecolândia landscape (section 2, Fig. 7A), indicating a long-term history of fluvial deposition when combined with the underlying Unit 1 . Numerous, laterally related concave-up geometries of the basal surface indicate multiple and narrow channels of possible braided-channel planform; the geometries are interpreted as bar-set growth within the channel (section 5, Fig. 7B).

The radar facies in Unit 3 have a distinct pattern and present characteristics other than the strictly fluvial facies. In the lower areas, where freshwater lakes are connected during the flood seasons, the reflections are nearly horizontal, continuous and concordant. This pattern can be attributed to deposition by

Table 1. Radar facies descriptions and respective interpretations.

\begin{tabular}{|c|c|c|}
\hline Radar facies & Description & Interpretation \\
\hline (1) & $\begin{array}{l}\text { Unit } 1 \text { (beneath the red line) is mainly } \\
\text { represented by a chaotic pattern ( } 1 \text { to } \\
1.5 \mathrm{~m} \text { deep) with horizontal filling; } \\
\text { basal reflections show low-amplitude } \\
\text { (decimetric), concave-up shape. }\end{array}$ & $\begin{array}{l}\text { These features indicate possible channel } \\
\text { deposition of markedly varying flow regimes } \\
\text { resulting in channel fill by alternating upper and } \\
\text { lower flow regime. Concave-up surfaces at the } \\
\text { base of this succession indicate significant base- } \\
\text { level drop and incision of fluvial channels into } \\
\text { older sediments. }\end{array}$ \\
\hline 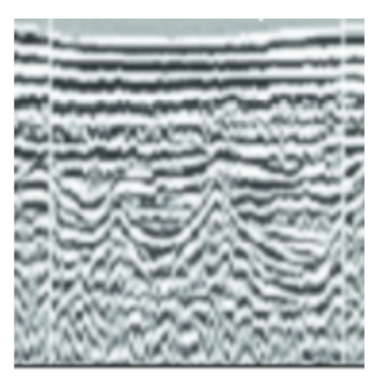 & $\begin{array}{l}\text { The base of Unit } 2 \text { (intermediate - between } \\
\text { blue and red lines) is very irregular and } \\
\text { characterized by concave-up geometries. } \\
\text { Its thickness varies from approximately less } \\
\text { than } 1 \mathrm{~m} \text { up to } 4 \mathrm{~m} \text {; base shows erosional } \\
\text { truncation. The radar facies present } \\
\text { subparallel, oblique, concave-upward forms, } \\
\text { approximately } 10 \mathrm{~m} \text { wide and from } 1 \text { to } 3 \mathrm{~m} \\
\text { deep, separated from each other by } 1 \mathrm{~m} \text { to } 2 \\
\mathrm{~m} \text {, and offlap geometries. }\end{array}$ & $\begin{array}{l}\text { Reflections of Unit } 2 \text { (intermediate) exhibit } \\
\text { erosive bases and aggrading geometry; } \\
\text { recording deposits of fluvial systems. Concave- } \\
\text { up forms record multiple and narrow channels } \\
\text { of possibly braided-channel planform, and the } \\
\text { geometries are interpreted as bar-set growth } \\
\text { within channels. }\end{array}$ \\
\hline $\begin{array}{l}\text { disconformity } 2 \\
\text { disconformity } 1\end{array}$ & $\begin{array}{l}\text { Unit } 3 \text { (above the blue line) is } \\
\text { approximately } 2 \mathrm{~m} \text { to } 4 \mathrm{~m} \text { thick, and is } \\
\text { characterized by a flat and slightly sinuous } \\
\text { base. Radar facies are characterized by } \\
\text { a moderately continuous and roughly } \\
\text { parallel internal decimetric reflections } \\
\text { that can laterally present divergent and/ } \\
\text { or convergent configurations. Radar } \\
\text { facies geometries also indicate vertical } \\
\text { aggradation in the lower units. }\end{array}$ & $\begin{array}{l}\text { Radar facies of Unit } 3 \text { present distinct } \\
\text { characteristics from the underlying fluvial } \\
\text { facies. In the lower areas where freshwater lakes } \\
\text { are connected during the flood seasons, the } \\
\text { reflections are near horizontal, continuous and } \\
\text { concordant. This pattern can be attributed to } \\
\text { deposition by unconfined sheet-flow processes } \\
\text { during flooding. } \\
\text { Reflections of Unit } 3 \text { are slightly convex upward } \\
\text { in the studied sections, and are perpendicular } \\
\text { to the sand ridge in the Eastern border of the } \\
\text { Lindoia saline. }\end{array}$ \\
\hline
\end{tabular}



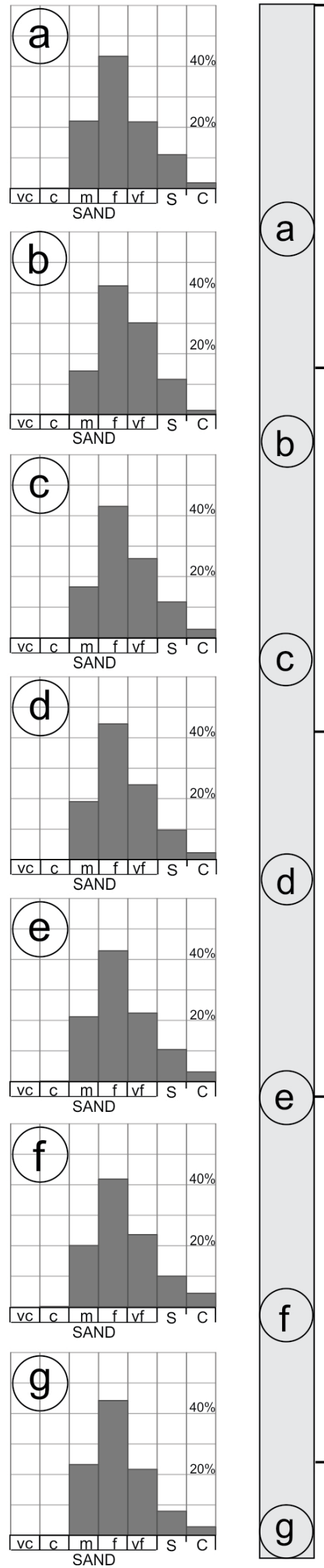

$8.77 \pm 0.93 \mathrm{ka}$

Source: modified from Mendes (2015).

Figure 8. OSD dating of samples (a-g) collected from a $2.1 \mathrm{~m}$ deep pit excavated in the sand ridge (Unit 3; location as shown in Figure 3). The profile is composed of average diameter sediments from fine to very fine sands (histograms of particle size distribution on the left). The ages indicate continuous accumulation during the Holocene. unconfined sheet-flow processes during flooding. Locally, the reflections of Unit 3 are slightly convex upward in the sections, and they are perpendicular to the sand ridge on the eastern border of the Lindoia saline (Fig. 4). Sedimentological analyses on such sediments show moderate to well-sorted fine- and medium-grained sands (Soares et al. 2003, Mendes 2015).

An eolian origin during the Late Pleistocene maximum and glacial maximum was previously proposed by many publications in order to explain the sand ridges (Almeida 1945, 1959, Klammer 1982, Tricart 1982, Soares et al. 2003). Based on seven OSL dating of sand samples collected in a 2.1 meters deep pit (Fig. 8), Mendes (2015) interpreted that sand ridges were formed by eolian sand accumulation during the Holocene. A significant period of eolian deflation during the early and middle Holocene is considered to have occurred before establishing the perennial lakes in the Nhecolândia around 3,300-3,200 cal yrs BP (McGlue et al.2017, Guerreiro et al.2018). While our data clearly demonstrates the non-channelized nature of the processes responsible for the deposition of Unit 3, it is yet unclear if it was deposited by sheet-flow or eolian processes, or indeed a combination of both.

\section{CONCLUSION}

The GPR technique applied to the sedimentation study in the Taquari megafan provided continuous sections of good quality in both directions (parallel and perpendicular to the main channel flow). Using a frequency of $100 \mathrm{MHz}$ was a good compromise between depth of investigation and resolution, reaching depths of up to $8 \mathrm{~m}$ and decimetric vertical detail. Therefore, the GPR technique has been successfully used in the sand-prone emersed areas of the Pantanal Basin to study shallow sedimentation structures.

The identification of two disconformities allowed the recognition of three high-frequency depositional sequences. The two older sequences record channelized forms and similar radar facies, which are related to laterally migrating channel and barform deposits.

The younger depositional sequence presents continuous and parallel reflections that indicate vertical aggradation, initiated by the end of the Pleistocene and continued throughout the Holocene. There is a strong correlation between the younger sequence's radar facies and the depositional forms preserved in the landscape. This suggests that these features were not formed by channelized fluvial streams, but rather by sheet-flood and/or eolian processes.

\section{ACKNOWLEDGMENTS}

The authors acknowledge the São Paulo Research Foundation (FAPESP; grants \#2014/06889-2 and \#2014/13937-3); the Brazilian National Council for Scientific and Technological Development (CNPq; grant \# 432985/2018-2) for financial support.; the Luminescence and Gamma Spectrometry Laboratory (LEGaL) at the University of Sao Paulo for OSL dating facilities; Antonio Paranhos Filho for providing precise altimetric measurements along section 2; Lucas and Marina Leuzinger, of Fazenda Barranco Alto, for allowing the surveys and for the lodging facilities; and Drs. Richardson Abraham Jr., Eder Renato Merino, and Amanda Santa Catharina for the language revision and editing; M.L.A is a research fellow of CNPq/Brazil. 


\section{ARTICLE INFORMATION}

Manuscript ID: 20200211. Received on: 03/12/2020. Approved on: 01/26/2021.

Author F.T. provided the GPR data, wrote the first draft of the manuscript and prepared Figures 4, 5, 6, 7, and Table 1; Author M.S. wrote the interpretation of the radar facies and also prepared Figures 4, 5, 6, 7; Author D.M. contributed with the interpretation, with the borehole and dating data and prepared Figure 8; Author M.L.A. wrote the regional and local geology of the Pantanal and prepared Figures 1, 2 and 3, revised and improved the manuscript.

Competing interests: The authors declare no competing interests.

\section{REFERENCES}

Ab'Saber A.N. 1988. O Pantanal Mato-grossense e a teoria dos refúgios. Revista Brasileira de Geografia, 50:9-57.

Almeida F.F.M. 1945. Geologia do Sudoeste Mato-grossense. Boletim da Divisão de Geologia e Mineralogia, 116:19-25.

Almeida F.F.M. 1959. Traços gerais da geomorfologia do Centro-Oeste brasileiro. In: Almeida FFM, Lima MA (eds.). Planalto Centro-Ocidental e Pantanal Matogrossense. Guia de Excursão n ${ }^{\circ} 1$ do XVIII Congresso Internacional de Geografia. Rio de Janeiro: Conselho Nacional de Geografia, p. 7-65.

Almeida T.I.R., Calijuri M.C., Falco P.B. Casali S.P., Kupriyanova E., Paranhos Filho A.C., Sigolo J.B., Bertolo R.A. 2011. Biogeochemical processes and the diversity of Nhecolândia lakes, Brazil. Anais da Academia Brasileira de Ciências, 83(2):391-407. https://doi.org/10.1590/ S0001-37652011000200004

Assine M.L. 2003. Sedimentação na Bacia do Pantanal Mato-Grossense, Centro-Oeste do Brasil. Tese de Livre-Docência, Instituto de Geociências e Ciências Exatas, Universidade Estadual Paulista "Júlio de Mesquita Filho", Rio Claro, $106 \mathrm{p}$

Assine M.L. 2005. River avulsions on the Taquari megafan, Pantanal wetland, Brazil. Geomorphology, 70(3-4):357-371. https://doi.org/10.1016/j. geomorph.2005.02.013

Assine M.L. 2015. Brazilian Pantanal: A Large Pristine Tropical Wetland. In: Vieira B.C., Salgado A.A.R., Santos L.J.C. (eds.). Landscapes and Landforms of Brazil (p. 135-146). Netherlands: Springer (World Geomorphological Landscapes).

Assine M.L., Macedo H.A., Stevaux J.C., Bergier I., Padovani C.R., Silva A. 2015a. Avulsive Rivers in the Hydrology of the Pantanal Wetland. In: Bergier I., Assine L.M. (Eds.). Dynamics of the Pantanal Wetland in South America (p. 83-110). Switzerland: Springer International Publishing.

Assine M.L., Merino E.R., Pupim F.N., Macedo H.A., Santos M.G.M. 2015b. The Quaternary alluvial systems tract of the Pantanal Basin, Brazil. Brazilian Journal of Geology, 45(3):475-489. https://doi. org/10.1590/2317-4889201520150014

Assine M.L., Merino E.R., Pupim F.N., Warren L.V., Guerreiro R.L., McGlue M.M., 2015c. Geology and Geomorphology of the Pantanal Basin. In: Bergier I., Assine L.M. (Eds.). Dynamics of the Pantanal Wetland in South America (p. 23-50). Switzerland: Springer International Publishing.

Assine M.L., Padovani C.R., Zacharias A.A., Angulo R.J., Souza M.C. 2005. Compartimentação geomorfológica, processos de avulsão fluvial e mudanças de curso do Rio Taquari, Pantanal Mato-Grossense. Revista Brasileira de Geomorfologia, 6(1):97-108. https://doi.org/10.20502/rbg.v6i1.43

Assine M.L., Soares P.C. 2004. Quaternary of the Pantanal, west-central Brazil. Quaternary International, 114:23-34. https://doi.org/10.1016/ S1040-6182(03)00039-9

Barbiéro L., Queiróz-Neto J.P., Ciornei G., Sakamoto A.Y., Cappelari B., Fernandes E., Valles V. 2002. Geochemistry of water and ground water in the Nhecolândia, Pantanal of Mato Grosso, Brazil: variability and associated process. Wetlands, 22:528-540. https://doi. org/10.1672/0277-5212(2002)022[0528:GOWAGW]2.0.CO;2

Barbiéro L., Rezende Filho A., Furquim S.A.C., Furian S., Sakamoto A.Y., Valles V., Graham R.C., Fort M., Ferreira R.P.D., Queiroz Neto J.P. 2008. Soil morphological control on saline and freshwater lake hydrogeochemistry in the Pantanal of Nhecolândia, Brazil. Geoderma, 148(1):91-106. https://doi. org/10.1016/j.geoderma.2008.09.010

Bergier I., Krusche A., Guérin F. 2014. Alkaline lakedynamics in the Nhecolândia Landscape. In: Bergier I., Assine M.L. (Eds.). Dynamics of the Pantanal Wetland in South America (p. 145-161). Switzerland: Springer International Publishing.
Bridge J.S., Alexander J., Collier R.E.L., Gawthorpe R.L., Jarvis J. 1995. Ground-penetrating radar and coring used to study the large-scale structure of point-bar deposits in three dimensions. Sedimentology, 42(6):839-852. https://doi.org/10.1111/j.1365-3091.1995.tb00413.x

Bristow C.S., Jol H.M. (Eds.). 2003. Ground Penetrating Radar in Sediments. London: Geological Society Special Publications, 330 p.

Colinvaux P.A., Oliveira P.E., Bush M.B. 2000. Amazonian and neotropical plant communities on glacial time-scales: the failure of the aridity and refuge hypotheses. Quaternary Science Reviews, 19(1-5):141-169. https://doi. org/10.1016/S0277-3791(99)00059-1

Davis J.L., Annan A.P. 1989. Ground-penetrating radar for high-resolution mapping of soil and rock stratigraphy. Geophysical Prospecting, 37(5):531551. https://doi.org/10.1111/j.1365-2478.1989.tb02221.x

Evans T.L., Costa M. 2013. Landcover classification of the Lower Nhecolândia subregion of the Brazilian Pantanal Wetlands using ALOS/ PALSAR, RADARSAT-2 and ENVISAT/ASAR imagery. Remote Sensing of Environment, 128:118-137. https://doi.org/10.1016/j.rse.2012.09.022

Furian S., Martins E.R.C., Parizotto T.M., Rezende-Filho A.T., Victoria R.L., Barbiero L. 2013. Chemical diversity and spatial variability in myriad lakes in Nhecolândia in the Pantanal wetlands of Brazil.Limnology and Oceanography, 58(6):2249-2261. https://doi.org/10.4319/lo.2013.58.6.2249

Furquim S.A.C., Graham R.C., Barbiero L., Queiroz Neto J.P., Vidal-Torrado P. 2010. Soil mineral genesis and distribution in a saline lake landscape of the Pantanal Wetland, Brazil. Geoderma, 154(3-4):518-528. https://doi. org/10.1016/j.geoderma.2009.03.014

Guerreiro R.L., McGlue M.M., Stone J.R., Bergier I., Parolin M., Silva Caminha S.A., Warren L.V., Assine M.L. 2018. Paleoecology explains Holocene chemical changes in lakes of the Nhecolândia (Pantanal-Brazil). Hydrobiologia, 815(1):1-19. https://doi.org/10.1007/s10750-017-3429-3

Jol H.M., Bristow C.S. 2003. GPR in sediments: advice on data collection, basic processing and interpretation, a good practice guide. In: Bristow C.S., Jol H.M. (eds.). Ground Penetrating Radar in Sediments (p. 9-27). London: Geological Society Special Publications.

Junk W.J., da Cunha C.N., Wantzen K.M., Petermann P., Strüssmann C., Marques M.I., Adis J. 2006. Biodiversity and its conservation in the Pantanal of Mato Grosso, Brazil. Aquatic Sciences, 68:278-309. https://doi. org/10.1007/s00027-006-0851-4

Klammer G. 1982. Die Paläovüste des Pantanal von Mato Grosso und die pleistozäne Klimageschichte der brasilianischen Randtropen. Zeitschrift für Geomorphologie, 26:393-416.

Lopes M., Fornari M., Taioli F. 2013. Characterization of the architecture of fluvial bars of the Amazon and Tapajós rivers using GPR (ground penetrating radar). In: International Congress of the Brazilian Geophysical Society, 13., Rio de Janeiro. Annals ... p. 7. CD-ROM.

McGlue M.M., Guerreiro R.L., Bergier I., Silva A., Pupim F.N., Oberc V., Assine M.L. 2017. Holocene stratigraphic evolution of saline lakes in Nhecolândia, southern Pantanal wetlands (Brazil). Quaternary Research, 88(3):472-490. https://doi.org/10.1017/qua.2017.57

Mendes D. 2015. Geocronologia de formas deposicionais e evolução da planície interleques do rio Negro, quaternário da Bacia do Pantanal. Thesis, Instituto de Geociências e Ciências Exatas, Universidade Estadual Paulista "Júlio de Mesquita Filho", Rio Claro, 110 p.

Merino E.R., Assine M.L. 2020. Hidden in plain sight: how finding a lake in the Brazilian Pantanal improves understanding of wetland hydrogeomorphology. Earth Surface Processes and Landforms, 45(2):440458. https://doi.org/10.1002/esp.4745 
Neal A. 2004. Ground-penetrating radar and its use in sedimentology: principles, problems and progress. Earth-Science Reviews, 66(3-4):261-330. https://doi.org/10.1016/j.earscirev.2004.01.004

Por F.D. 1995. The Pantanal of Mato Grosso (Brazil). World's largest wetlands, Monogr. Biol. 73. Dordrecht, Boston, London, Kluwer Acad. Publ., 122 p.

Porsani J.L., Assine M.L., Moutinho L. 2005. Application of GPR in the Study of a Modern Alluvial Megafan: The Case of the Taquari River in Pantanal Wetland, West-Central Brazil. Subsurface Sensing Technology and Applications, 6(2):219-233. https://doi.org/10.1007/s11220-005-0008-x

Posamentier H.W., Allen G.P. 1999. Siliciclastic sequence stratigraphy: concepts and applications. SEPM Concepts in Sedimentology and Paleontology, 7:210. https://doi.org/10.2110/csp.99.07

Posamentier H.W., Vail P.R. 1988. Eustatic controls on clastic deposition. II. Sequence and systems tract models. In: Wilgus C.K., Hastings B.S., Kendall, C.G.St.C., Posamentier H.W., Ross C.A., Van Wagoner J.C. (Eds.). Sea Level Changes: An Integrated Approach (42, p. 125-154). Tulsa: SEPM Special Publication.

Smith G.H.S., Ashworth P.J., Best J.L., Lunt I.A., Orfeo O, Parsons D.R 2009. The sedimentology and alluvial architecture of a large braid bar, Rio Paraná, Argentina. Journal of Sedimentary Research, 79(8):629-642. https:// doi.org/10.2110/jsr.2009.066

Smith G.H.S., Ashworth P.J., Best, J.L., Woddward J., Simpson G.J. 2006. The sedimentology and alluvial architecture of sandy braided South Saskatchewan river, Canada. Sedimentology, 53(2):413-434. https://doi. org/10.1111/j.1365-3091.2005.00769.x

Soares A.P., Soares P.C., Assine M.L. 2003. Areiais e lagoas do Pantanal, Brasil: herança paleoclimática? Revista Brasileira de Geociências, 33:211-224. https://doi.org/10.25249/0375-7536.2003332211224

Souza L.A.P., Porsani J.L., Souza O.C., Moutinho L. 2002. Levantamento Experimental GPR no Rio Taquari, Bacia do Pantanal Matogrossense. Revista Brasileira de Geofísica, 20(1):67-72. https://doi.org/10.1590/ S0102-261X2002000100006
Tamura L.N., Almeida R.P., Taioli F., Marconato A., Janikian L. 2016. Ground Penetrating Radar investigation of depositional architecture: the São Sebastião and Marizal formations in the Cretaceous Tucano Basin (Northeastern Brazil). Brazilian Journal of Geology, 46(1):15-27. https:// doi.org/10.1590/2317-4889201620150031

Tatum D.I., Francke J. 2012. Constructing hydrocarbon reservoir analogues of eolian systems using ground penetrating radar. Journal of Applied Geophysics, 81:21-28. https://doi.org/10.1016/j.jappgeo.2011.09.014

Tricart J. 1982. El Pantanal: un ejemplo del impacto geomorfologico sobre el ambiente. Informaciones Geograficas, (29):81-97. https://doi. org/10.5354/0719-5370.2013.27673

Ussami N., Shiraiwa S., Dominguez J.M.L. 1999. Basement reactivation in a sub-Andean foreland flexural bulge: The Pantanal Wetland, SW Brazil. Tectonics, 18(1):25-39. https://doi.org/10.1029/1998TC900004

Vail P.R., Mitchum R.M., Jr., Todd R.G., Widmier J.M., Thompson S., III, Sangree J.B., Bubb J.N., Hatlelid W.G. 1977. Seismic stratigraphy and global changes of sea level. In: Payton C.E. (Ed.). Seismic Stratigraphy: Applications to Hydrocarbon Exploration (26, p. 49-212). American Association of Petroleum Geologists. https://doi.org/10.1306/M26490C3

Van Overmeeren R.A. 1998. Radar facies of unconsolidated sediments in The Netherlands: A radar stratigraphy interpretation method for hydrogeology. Journal of Applied Geophysics, 40(1):1-18. https://doi. org/10.1016/S0926-9851(97)00033-5

Van Wagoner J.C., Posamentier H.W., Mitchum R.M., Vail P.R., Sarg J.F., Loutit T.S., Hardenbol J. 1988. An overview of sequence stratigraphy and key definitions. In: Wilgus C.K., Hastings B.S., Kendall C.G.St.C., Posamentier H.W., Ross C.A., Van Wagoner J.C. (Eds.). Sea Level Changes - An Integrated Approach, 42, p. 39-45. Broken Arrow: SEPM Special Publication.

Zani H., Assine M.L., McGlue M.M. 2012. Remote sensing analysis of depositional landforms in alluvial settings: method development and application to the Taquari megafan, Pantanal (Brazil). Geomorphology, 161:82-92. https://doi.org/10.1016/j.geomorph.2012.04.003 